\title{
MENTALITY MANAGEMENT: MENTALITY FORMATION AND STRATEGY DEVELOPMENT
}

\author{
Liliia Voinycha \\ Lviv National Agrarian University, Ukraine \\ Roman Popivniak \\ Lviv National Agrarian University, Ukraine
}

\begin{abstract}
The goal of this article is to analyze problems relating to the mindset of the Ukrainian people as it pertains to Ukraine's integration into the European Union. Several different methods were used in this analysis. Comparative analysis identified similarities and differences between the peoples of the European Union and Ukraine.Also, an abstract-logical method was used to define the main problems relating to state support for democracy in Ukraine. Finally, a statistical-economic method was used to identify the existence and closeness of the connection between the standard of living and the perpetuation of corruption in Ukraine. The work analyses the principal directions and problems of mentality management for the people of Ukraine and finds that the strategy development for the Ukrainian personality should be focused not only on the self-improvement of each individual but also on developing practical recommendations for strengthening the democratic foundations of Ukrainian society.
\end{abstract}

Keywords: mentality management, strategy development, perception of corruption, standard of living

DOI: http://dx.doi.org/10.15549/jeecar.v7i2.407

\section{PROBLEM DEFINITION}

Relations between Ukraine and Europe are not just for a partnership in the present, but also for a common future. Geographically speaking, Ukraine is the center of Europe and therefore should not be considered as separate from it.

Indeed, Ukraine's partnership with the European Union (EU) is extremely important for the life of the country, and the partnership will be strong only if it is supported by the mental characteristics of Ukrainian citizens - and thus creating a close socio-cultural and spiritual space - and not conditioned just by geopolitical factors.

An analysis of the work of theorists and practitioners on the problems of the state of Ukraine in its path toward integration into the EU reveals several issues, such as an unstable political situation, an uncompetitive economic system, poor monetary and credit mechanisms, 
uncompetitive production etc. By looking at the essence of each of the problems and looking for a common element, however, it becomes clear that such problems are the result of something else, something deeper. Good questions to ask, then, is: What is that 'something deeper', what caused it, and how can it be dealt with?

If Ukraine can be considered as a complex, high-level system, it can theoretically be divided into separate interconnected elements that form a permanent mechanism. Individual subsystems form an economic system that, together with the cultural and historical features of the geographical region, form a state.

The leading countries of the world also have individual subsystems that combine to form a state, so it could be useful to find what common elements exist in their subsystems. Finding a common element between Ukraine's subsystems and those of the leading economies of the world could help understand the root causes of Ukraine's economic problems. Such an element is the interpersonal factors in the person who manages the state's politics, participates in the distribution of capital, keeps the monetary system in circulation and so on. Understanding objectively these interpersonal factors, therefore, can serve as a basis for building Ukraine's economy.

\section{ANALYSIS OF RECENT RESEARCH AND PUBLICATIONS}

Most philosophers and culturologists define mentality as a type of thinking brought to the subconscious automatism, which is manifested in the system of values that underpin the content of being a community and an individual. Mentality is many faceted in nature; it is at the same time mental, unconscious, natural, biological and social, instilled in education and tradition.

According to the culturologist M. Shlemkevich (Shlemkevich,1954), a component of the Ukrainian mentality is closely and organically linked to introversion and individualism. Ukrainians also are characterized by an attraction to democratic, republican forms of government, yet at the same time individualism (which can lead to selfishness, ambition) causes conflicts in the struggle for power. This conflict manifests itself in the inability of Ukrainians to form a strong state and secure its independence and power (Dzioba, 2008).

Ironically, for Ukrainians there is a timeless desire to live in such a state. A. Sheptytsky has said that there is a strong will in the soul of a Ukrainian to have his own state, but this state should be exactly what a certain party, group or even individual wants to have. Therefore, every Ukrainian national case is destroyed by fatal distribution, strife and lack of consent. Certainly, the Ukrainian national idea is not identified with the Ukrainian mentality (Galushko, 2009), Ukrainian traditions and virtues. Rather, its purpose is to ensure Ukrainian self-fulfillment and to realize national interests in all spheres of existence.

The theoretical and methodological bases of our study were positions of national and foreign scientific literature on the problems of state formation in Ukraine and the formation of the mechanism of state influence on personality development; the formation of mentality.

\section{FORMULATION OF OBJECTIVES}

Consideration of the problem of state formation will give an opportunity to formulate a strategy for the development of the Ukrainian personality, to create a mechanism of state influence on individuality in different spheres of society, and also help to find possible ways of solving numerous problems of the state.

\section{PRESENTATION OF KEY RESEARCH FINDINGS}

Research should not be conducted on the consideration of the characteristics of individuals, because by doing so we divide society into separate parts when it, essentially, is a whole. It is worth it, therefore, to find a common point of contact for all people living in Ukraine. And the concept that accumulates the aggregate experience of generations, describes beliefs, values, the attitude of the individual to the state, etc. is a mentality.

Mentality is a multifaceted category that is difficult to explore accurately. On the surface are such components as rules, traditions, customs, visions of the world, language, but deeper subconscious behavior is hidden. Mentality is a category characterized by non- 
stratification; that is, the mentality is one for the nation and does not define the mentality of the peasant and the mentality of the intelligentsia (Galushko, K., 2009). All components of the mentality can be theoretically divided into several components, among which are:

- Common culture - family relationships, values, rituals, pattern inactive behavior.

- Spiritual culture - the culture of a community, its features that are reflexive; that is, it arises as a reaction to something.

- Social response - the reaction of society to politics, statehood, reforms, power.

The last component, in our opinion, plays one of the main roles in the development of the state. After all, the reaction to something becomes the beginning of actions, which in the positive scenario gives the maximum positive effect, or inaction, which in the form of neutrality, conformism and the perception of negativity as an unchanging reality, destroys all possibilities of economic, social and spiritual development of the state.

It is important for the vast majority of people to have in common their own position and that of the state, and above all to focus on a national idea that binds the public and creates an additional synergy effect. In our view, the management of the nation's mentality should be viewed from the standpoint of a systematic approach.

It is hard to argue that any nation is endowed with inherent psychological and socio-cultural characteristics, which is the engine of unity of a people of one community (a system of individuals with a certain mentality). If this mentality includes the experience of generations, accordingly it can change, evolve. This change in the socio-cultural environment will result in the movement of the nation's mentality to a new level (to ensure the emergence of the system).

The structuring of elements at the system level allows effect-forming factors to be revealed that, using appropriate economic and mathematical tools, show not only the existing relationship between factors (input variables, which in the corresponding mathematical models are called factor-arguments, exogenous, predecessors independent) and the resultant indicators (endogenous, dependent, or explanatory), but also the degree of correlation between them. With appropriate correlationregression models, it is possible to identify priority measures to improve the system.

The factor is the carrier of influence on the system, which leads to a change of its indicators. The factors are internal and external. If the former are factors of human activity that are controlled from the point of view of managing the macrosystem, then the latter, affecting the system, are unmanaged. Since the classification of factors is the basis for the classification of reserves, the purpose of statistical analysis is to identify the most influential among them and to develop the reserve-specific directions of their influence on the improvement of the system. As the starting factor of this study, we have chosen the standard of living of the population of states, which is determined by numerous international organizations, as the indicator.

In our view, data that can reflect a country's mentality may be indicative of the level of perception of corruption and democracy. The ability to use these indicators in a direct link explains man's relation to corruption and democracy, the relationship of man to injustice and bribery in the country; people are willing to change, to influence the affairs of the state; shows openness and willingness of people to change, publicity, personal freedom, etc. In particular, the perception of corruption is determined precisely by the intrinsic characteristics of the person, and from the point of view that, if the citizen does not give a bribe against corruption, there is no bribe and there are no bribers. Justifying people for the inability to carry out any activity without the above manipulations also reflects their desire to change something, because here we can observe inaction and refusal to turn such a system into a transparent and corruption-free system. With regard to democracy, it represents an opportunity to exercise institutional freedom, which in turn is based on the exercise of the rights and freedoms of citizens provided by the state.

The start of regression analysis begins with data collection. Perception of corruption has been provided by Transparency International, 
which has been conducting such surveys since 1995, and the calculation methodology includes both objective fixed facts and subjective judgments of citizens and entrepreneurs obtained through 13 surveys of reputable international institutions and research centers. The key indicator of the index, which is evaluated only in the public sector, is the number of points; a maximum score of 100 points indicates the absence of corruption in the life of the state. According to the organization's research, in 2018 Ukraine gained 32 points and climbed from 130 to 120 in the overall international rating of the Corruption Perceptions Index. However, Ukraine's neighbors have much better results: Moldova 33, Poland - 60, Belarus - 44, Hungary - 46, Romania - 47, Slovakia - 50, Russia - 28 (Corruption perception index, 2018).

The Legatum Institute in London annually assesses the standard of living. It placed Ukraine on a so-called prosperity index, which is calculated by the following indicators: economy, business, government, education, public health, social capital, environment, security and personal freedoms. In the overall ranking, Ukraine's prosperity index fell 5 positions from 107 to 112 in the previous year (Legatum Prosperity Index, 2018).

To assess the level of elected democracy, the Democracy Index from the Economic Intelligence Unit, was used. This index uses 60 indicators grouped into five categories: elections and pluralism, civil liberties, government, political engagement population, political culture. According to the Economic Intelligence Unit, Ukraine is characterized as a "hybrid democracy" in which there is no true rule of law, no independent judiciary, widespread corruption, and problems in the operation of the control system (Democracy Index, 2018).

For a visual assessment rating of life and the perception of corruption, apply these values on the graph (Fig.1).

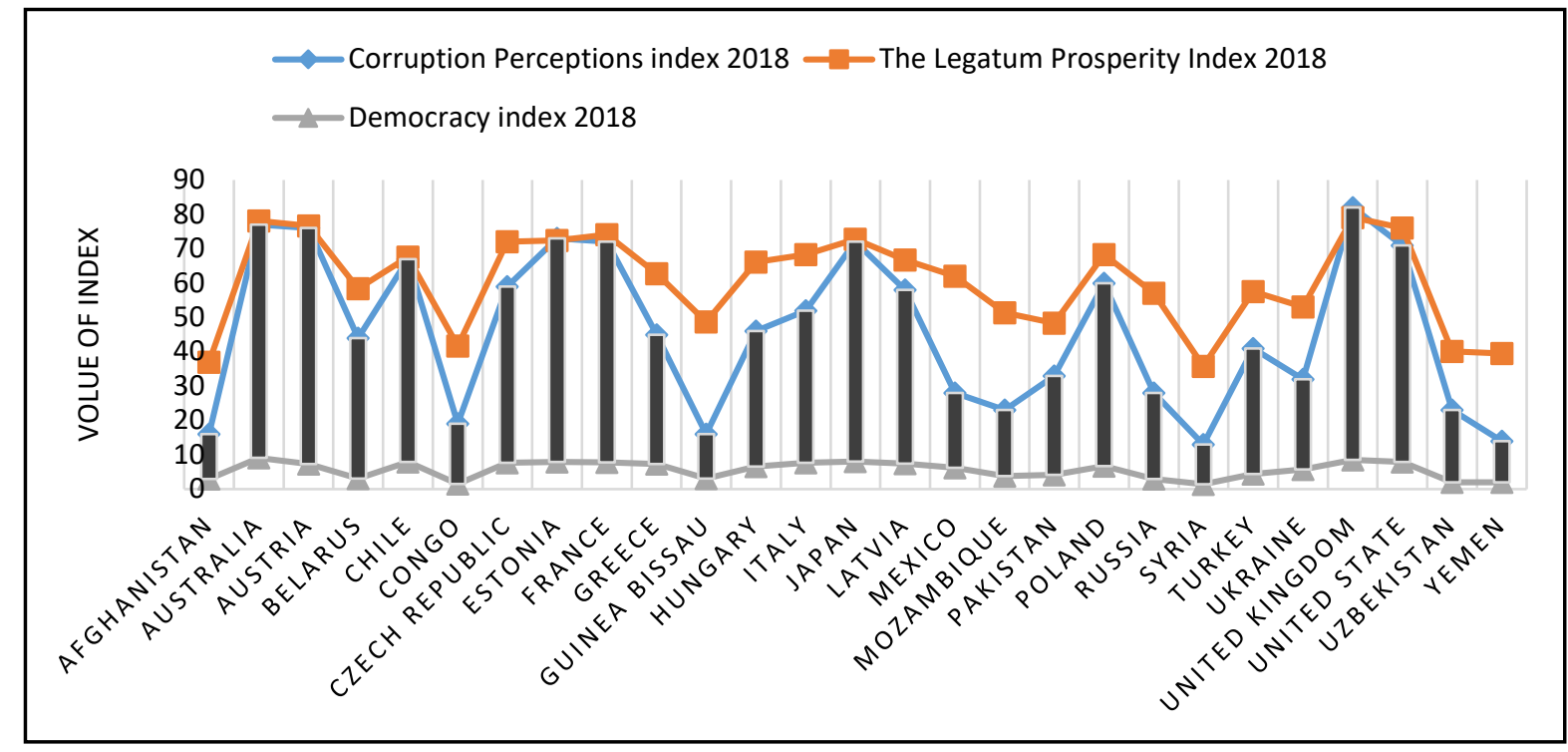

* the number of horizontal axis signatures match the number of studied countries.

Figure 1: Living standards, perceptions of corruption and democracy level in the studied countries. Source: Completed by the authors according to the data (Corruption perception index (2018)), (Legatum Prosperity Index (2018), (Democracy Index (2018)

As we can see, without even doing a numerical analysis of the data, such a relationship exists. Leading corruption countries are world leaders in living standards and vice versa.

Analyzing the impact of intersystem factors 
on raising the standard of living for the state population, it is advisable to use modern mathematical methods of statistical data processing. This toolkit can provide computer support to solve a key problem in any study: how to identify and describe the relationships between them (Yatsiv, Kolodiichuk, 2017) based on partial results of statistical observation of events or metrics

Influence mentality that presents a corruption perception index and an index of democracy, and in the aggregate and the Legatum Prosperity Index is conveniently described by the Cobb-
Douglas equation (Harasym, Klym, Hrytsak, 2019; Shumskaya, 2007),

$$
Y=f(K ; L)
$$

This function determines the relationship between the development of country $Y$ with the factors that reflect the mentality of the country the Corruption Perception Index - $K$ and the Democracy Index - $L$, where the possibility and limited substitution of factors are significant (Figure 2).

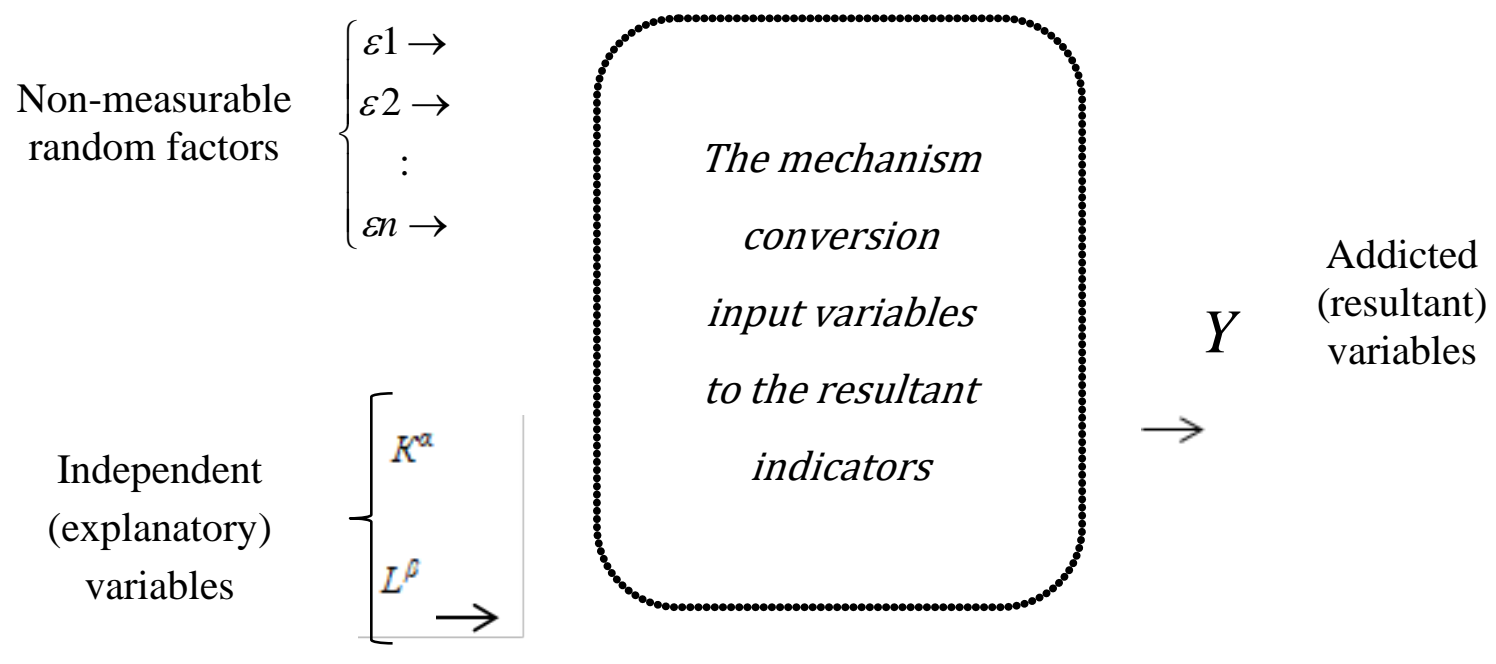

Figure. 2: General scheme of dependencies of efficiency variables managing the standard of living of countries during their statistical survey.

Source: Completed by the authors according to the data (Yatsiv, Kolodiichuk, 2017), (Vilchinskaya, 2016)

We selected 27 countries that were evaluated by the abovementioned organizations for the study (Table 1). Non-inclusion of individual countries in the analysis is explained by the lack of the necessary data to evaluate them. Analysis of the results of correlation-regression analysis allows us to reach the following conclusions:

There is a strong enough relationship between the investigated variables of the studied system; the structure of these relationships and their density are characterized by pair correlation coefficients.

Thus, the linear function becomes:

$$
Y_{t}=0,16324 X_{1}+0,25286 X_{2}+2,88421 \text {, }
$$

In this case, $a_{0}=e^{a}=e^{2.884208}=17,88939$, and we obtain the Cobb-Douglas function:

$$
\mathrm{Y}_{1}=17,88939 \mathrm{~K}^{0,16324} \mathrm{~L}^{0,25286} \text {, }
$$

Analysis of the degree of adequacy of regression equations derived from coefficients of determination $\left(R^{2}=0,92\right), F$-criterion and its level of significance of $p$-value and research residues regression models with graphic visualization diagram scattering remnants give reason to believe that enough linear regression models adequately describe the relationship between variables. 
Table 1: Output data for calculation the equation Cobb-Douglas

\begin{tabular}{|c|c|c|c|c|c|c|}
\hline Country (t) & $\begin{array}{c}\text { Corruption } \\
\text { Perceptions } \\
\text { index } 2018(\mathrm{Yt})\end{array}$ & $\begin{array}{c}\text { The Legatum } \\
\text { Prosperity Index } \\
2018(\mathrm{Kt})\end{array}$ & $\begin{array}{l}\text { Democrac } \\
\text { y index } \\
2018(\mathrm{Lt})\end{array}$ & $\operatorname{Ln}(Y t)$ & $\operatorname{Ln}(\mathrm{Kt})$ & $\operatorname{Ln}(\mathrm{Lt})$ \\
\hline Afghanistan & 16 & 36,9 & 2,97 & 2,772 & 3,608 & 1,088 \\
\hline Australia & 77 & 78,1 & 9,09 & 4,343 & 4,357 & 2,207 \\
\hline Austria & 76 & 76,6 & 7,29 & 4,330 & 4,339 & 1,986 \\
\hline Belarus & 44 & 58,4 & 3,13 & 3,784 & 4,066 & 1,141 \\
\hline Chile & 67 & 67,6 & 7,97 & 4,204 & 4,213 & 2,075 \\
\hline Congo & 19 & 41,7 & 1,49 & 2,944 & 3,729 & 0,398 \\
\hline Czech Republic & 59 & 72,1 & 7,69 & 4,077 & 4,277 & 2,039 \\
\hline Estonia & 73 & 72,4 & 7,97 & 4,290 & 4,282 & 2,075 \\
\hline France & 72 & 74,1 & 7,8 & 4,276 & 4,304 & 2,054 \\
\hline Greece & 45 & 62,7 & 7,29 & 3,806 & 4,138 & 1,986 \\
\hline Guinea Bissau & 16 & 48,7 & 3,14 & 2,772 & 3,885 & 1,144 \\
\hline Hungary & 46 & 66,1 & 6,63 & 3,828 & 4,191 & 1,891 \\
\hline Italy & 52 & 68,3 & 7,71 & 3,951 & 4,223 & 2,042 \\
\hline Japan & 72 & 72,8 & 7,99 & 4,276 & 4,287 & 2,078 \\
\hline Latvia & 58 & 66,7 & 7,38 & 4,060 & 4,200 & 1,998 \\
\hline Mexico & 28 & 61,9 & 6,19 & 3,332 & 4,126 & 1,822 \\
\hline Mozambique & 23 & 51,4 & 3,85 & 3,135 & 3,939 & 1,348 \\
\hline Pakistan & 33 & 48,4 & 4,17 & 3,496 & 3,878 & 1,427 \\
\hline Poland & 60 & 68,3 & 6,67 & 4,094 & 4,224 & 1,897 \\
\hline Russia & 28 & 57,1 & 2,94 & 3,332 & 4,044 & 1,078 \\
\hline Syria & 13 & 35,8 & 1,43 & 2,564 & 3,577 & 0,357 \\
\hline Turkey & 41 & 57,5 & 4,37 & 3,713 & 4,051 & 1,474 \\
\hline Ukraine & 32 & 53,1 & 5,69 & 3,465 & 3,971 & 1,738 \\
\hline United Kingdom & 82 & 79,1 & 8,53 & 4,406 & 4,370 & 2,143 \\
\hline United State & 71 & 76,0 & 7,96 & 4,262 & 4,330 & 2,074 \\
\hline Uzbekistan & 23 & 40,2 & 2,01 & 3,135 & 3,692 & 0,698 \\
\hline
\end{tabular}

Source: Completed by the authors according to the data (Corruption perception index 2018), (Legatum Prosperity Index 2018), (Democracy Index 2018):

Therefore, the constructed production function is characterized by reliable statistical characteristics.

Analysis of such dependence makes it possible to estimate the value of the input parameters in which the function prosperity index reaches a maximum (Shumskaya, 2007). The study of the prosperity function has shown that for some values of elasticity indicators, the maximum value of the prosperity function increases by several orders of magnitude, which is important for the strategic management of countries' mentalities.
In such circumstances, when considering the management of the mentality, the strategy for improving and developing the country under study should include two main clusters:

- a comprehensive enhancement of the individual as the key to success;

- a set of efforts of the state in mentality management.

Thus, the main problems of state support for farming enterprises in Ukraine include a low level of farming enterprises' knowledge concerning opportunities to obtain state support, as well as a complex procedure 
mechanism and obscure terms of obtaining state support, the manual mechanism of cost management, as well as insufficient amounts of financing from state programs.

In the authors' opinion, the efficiency of state support for domestic farming enterprises can be secured not only by an increase in the amount of budget financing, but also by establishing a clear procedure of the cost's utilization. Attempts to improve financial discipline while utilizing budget costs, by means of a complicated procedure of financial support supply, cause a loss of farming enterprises' interest concerning obtaining the support. The state support for farmers should be focused both on support of production output and producers' prices, as well as on support for implementation of innovative projects concerning sustainable land management by farmers.

The first cluster includes the correct internal beliefs and realizes that it is you as person that is most of what is needed for success. It is necessary to realize that achieving success is necessary and constant combination of efforts, and that success helps people to improve as human beings. This, in turn, helps push the chain "person-group-organization-industrycountry".

The second cluster should be fixed for the country, namely the legislative support of the national idea. A striking example is the Law of Ukraine "On the functioning of Ukrainian as the state language" on 25.04.2019 (Law of Ukraine, 2019), which helps to promote the use of the Ukrainian language among young people and civil servants. The use of language will provide an incentive for a deeper study of Ukrainian culture.

However, the role of government is not only Ukrainianization - strengthening Ukraine as a nation - but also in the creation and development of a strong personality through promoting healthy lives, the need for labor discipline and law-abiding citizens. The state, as the highest public opinion, has to take numerous steps to improve the climate in political life, to create institutions that would in some way be involved in the uptake of values. of course, mentality management is a comprehensive and continuous improvement of the determinants of the mentality to improve the Ukrainian nation's position in the world.

Such improvement in the face of the action of the two clusters should include the selfimprovement of each individual, observance of humanistic foundations, creation and support of a positive social climate, support and development of cultural heritage, thus formation of qualitatively new and important determinants of the Ukrainian mentality that would bring our country to a new one for us and so desirable a level - the plane of Europe; protecting one's own interests is to maintain the position of the positive determinants of the mentality achieved, as well as to counterbalance the influence of neighboring countries, especially the aggressively oriented ones.

\section{CONCLUSIONS}

The influence of psychological factors on the dynamics of living standards on the basis of the Cobb-Douglas equation showed that indicators of corruption perceptions of democracy have a positive impact on the prosperity of a nation.

Therefore, a management strategy to improve the mentality of Ukraine should be aimed at comprehensively shaping the personality and quality of public policy to support the national idea. Therefore, the author continues to focus on developing practical recommendations for strengthening the democratic foundations of Ukrainian society.

\section{REFERENCES}

About the functioning of Ukrainian as the state language (2019). Law of Ukraine, dated on April 25, 2019, № 2704-VIII. Retrieved from https://zakon.rada.gov.ua/laws/show/270419 [in Ukrainian].

Corruption perception index (2018). Retrieved from official https://www.transparency.org

Democracy Index (2018). Retrieved from https://www.eiu.com/topic/democracyindex

Dzioba, I. (2008). Юрій Шевельов. Вибрані праці: у 2-х книгах. II книга. 1151[in Ukrainian].

Harasym, P., Klym, N., Hrytsak, O. (2019). The taxation of subjects and objects of forestry enterprises in Ukraine: features, 
mechanisms and outlook. JEECAR Vol6 No2. 309-318

Galushko, K. (2009). Mentality, Encyclopedia of the History of Ukraine: Volume 6, 2009, 790. Retrieved from http://www.history.org.ua/?termin=Mental nist_[in Ukrainian].

Legatum Prosperity Index (2018). Retrieved from https://www.prosperity.com

Shlemkevich, M. (1954). Загублена українська людина. Київ [in Ukrainian].

Shumskaya, S. (2007). Instrument of production Function in the study of the Ukrainian Economy from http://eip.org.ua/docs/EP_07_4_104_uk.pdf [in Ukrainian]

Vilchinskaya, O. (2016). Identifying opportunities for application of the production function Cobb-Douglas as a tool for managing resources, Bulletin of KhmeInitsky National University, 2016, №2, 178-179[in Ukrainian].

Yatsiv, I., Kolodiichuk,V. (2017). Formation of so cial responsibility of large agricultural land users in Ukraine, Economic AnnalsXXI: Journal. № 168 (11-12), 48-52. [in Ukrainian].

\section{ABOUT THE AUTHORS}

Liliia Voinycha, email: voinycha@gmail.com

Dr. Liliia Voinycha holds the Ph.D. in Economics. She is the Associate Professor at the Department of Management of the Lviv National Agrarian University, Lviv. Her scope of scientific interests: educational management, strategic planning, regional labor market, human resources, knowledge economy. Dr. Voinycha published more than 80 scientific papers in professional journals in Ukraine and abroad.

Dr. Roman Popivniak holds the Ph.D. in Economics and works as the Associate Professor at the Department of Management in the Lviv National Agrarian University, Lviv. Dr. Popivniak is the author of 80 scientific papers, including two monographs and two textbooks. He has experience of teaching and scientific research in the system of higher education for more than twenty years. His scientific interests consist of the following: competitiveness, innovative activity, green tourism, and business planning. 